Original research article

\title{
Comrade Tito, it's all your fault! Yugoslav Citizens' Letters to Josip Broz Tito
}

\author{
DEJAN JOVIĆ \\ Faculty of Political Sciences, University of Zagreb
}

\begin{abstract}
Summary
Between 1945 and 1967, Josip Broz Tito, the Marshal and President of Yugoslavia, received 411,769 letters written by citizens of his country. Until 1964 he personally read most of the letters addressed to him and made decisions on requests and comments expressed in them. In this article we argue that Tito used the letters received to establish a direct link between himself and citizens. This was one of the key instruments of his power, as he used letters to conduct a permanent 'anti-bureauratic revolution' which would squeeze lower-level officials into a sandwich between him and 'the people'. We focus on one particular letter, written by Dragomir Katić, a 27-year old unemployed person from Kraljevo, Serbia. The letter arrived in February 1967, and Tito used this occasion to personally meet Katić. Despite Tito's promise, however, Katić's problem could not be solved for more than two years, due to a power struggle between Tito and local officials in Serbia. This case sheds new light on the nature of Tito's alleged absolute power in Yugoslavia. It tells us much about the attitude of dissatisfied individuals in Communist Yugoslavia, who cared much more about solving their personal problems than about changing the system, at least for as long as Tito was alive.
\end{abstract}

Keywords: Josip Broz Tito, Yugoslavia, Communism, Anti-bureaucratic Revolution, Dragomir Katić

\section{A Letter by Dragomir Katić}

On 10 February 1967, a 1,150-word letter arrived to the long-term President of the League of Communists of Yugoslavia (LCY), and the President of Yugoslavia, Josip Broz Tito. The writer of the letter was a certain Dragomir Katić, a 27-year old economist from Kraljevo in central Serbia. The letter was signed with his full name and surname, and with an address. It started by expressing some doubt that the letter would find its addressee: 
Dear Comrade Tito!

I am writing this letter to you, hoping that it would find its way to you (which, to be honest, I don't really believe), and that you will take all this only as being written with good intentions, and not as an action [motivated by] my complete disappointment - which [disappointment] was indeed not really small. All I am writing about here are my own personal views and my own personal experiences, and I am ready to defend every word of it, including in public discussion, if it needs to be.

The author then introduced himself to President Tito. He was born in 1936 in the village of Zaklopača, near Kraljevo, "in a poverty-stricken peasant family in which there were five children". In the war he lost his eldest brother and a sister, who were - according to his letter - participants in the National Liberation Struggle (NOB). His father was a prisoner of war. From prison he returned as a disabled person, and he had recently died of an illness which was caused by beatings and exposure to low temperature while in the PoW camp. Dragomir Katić himself was mildly disabled too - he was wounded in an accident as a child. Later, he completed, as a part-time student, the Higher Economic and Commercial School in Belgrade, working at the same time. In 1965, the year when Yugoslavia embarked on economic reforms which aimed at increasing efficiency and introducing further market-based principles and practices - just before he completed his studies - he was declared redundant, and was subsequently dismissed. Apparently, he said in the letter, he was not offered any alternative job. This is when his problems began:

Since then, alas, two and a half years have passed, and I have not been able to find a job. I have participated in more than 100 job competitions throughout Yugoslavia, of which at least 60 were in Kraljevo, and never have I been successful, apparently because I didn't satisfy criteria! Very weird! In more than 80 of these advertisements for a job they asked only for a middle-school education with 2-3 years of work experience. I did not get a job, although I have completed a higher education college, and although I explicitly underlined in my application letters that I 'would accept to work in this position regardless of the fact that it is for people with middle-school' and that I would not request a higher salary. In all cases I have been unsuccessful because others have 'offered better qualifications'! What 'better qualifications', I wonder?

Openly complaining about what he saw as injustice and unfairness, as well as possibly corrupt activities by those who provided jobs only for their friends and family, Dragomir K. then presented his main point:

I ask you, Comrade Tito, can this be allowed?... By the law and the logic of the system we live in, there is no way it should have happened like this, but it is happening - and massively so. Here I am walking from Heaven to Hell, from one 
place to another, from the chairman of the local municipal assembly to the secretary of the Municipal Committee of the LCY, then from him to the secretary of the Regional Committee in Kraljevo - and in all these places they give me nice promises, but - no work! Why are these comrades helpless to assist a man with solid qualifications? Why were 90 percent of these jobs in fact rigged, just formally advertised? This is done by the members of the LCY, who are sitting on various employment boards and panels.

When people want to get employed, they do not go to the Employment Agency but to Party Committees. It is good, he said, that people trust the Party and still consider it, as he said, the "highest instance of justice and fairness" in the country. The party officials, however, just listen, and do not really do anything to change things. They never investigate, and even more so: they do not bring to justice those who violate regulations.

If only 20 communists were brought to justice for favouritism, and if only 10 of them were excluded from the LCY, others would certainly think twice before they proceeded. But there is nobody to do that.

Various manipulators and even criminals can find a job, but not me, he then continued.

I am just as powerless as I am angry with this. Why should I - being 30 now waste my time at home, like some powerless grandma? Why can't I do anything, and I mean: absolutely anything? Whose fault is it that those who work have already deprived this society of several factories [by mismanaging them and producing loss], and [had they not done it] this would be enough to solve the problems of us, the unemployed. It is you, Comrade Tito! You [personally, Ti], and the Central Committee of the League of Communists of Yugoslavia. It's all your fault! It's your fault that we don't really know who really is a communist, and who is only called a communist... It's your fault that these things, completely unthinkable for a socialist society, are nevertheless happening here.

After such a direct accusation, Dragomir Katić continued:

Thus, I am requesting from you, and primarily from You personally, to be given a job... My duty as a communist is to be patient, and to not surrender but endure the worst. I think that I have endured enough and remained silent enough and that I no longer want to or will do that. There are jobs around - and it is up to you to see who is the one that is not giving a job to me! Who is playing games with us, small [ordinary] people, who have no God for an uncle, so that we receive what we do not deserve, and never what we deserve. At the end, I greet you comradely and cordially! 


\section{Letters to Tito in 1944-1964}

Dragomir Katić's letter was not the only one Comrade Tito received that year. In fact, it was just one of 24,961 letters received by the General Secretariat of the President of the Republic that year (1967), and one of more than 411,000 letters that were sent to him since he became the President of Yugoslavia (in 1953) and until the end of 1967. According to the analysis prepared in the Secretariat and presented to Tito on 23 February 1968, 182,929 people were received in person either by employees of the Secretariat, or - in very rare cases - by Tito himself. Before 1964, the letters had been delivered to Tito personally, and he would read many of them, making notes in the margins - usually decisions on how to act upon them, and/or what to reply. As of 1964, the restructuring of the Secretariat introduced the new practice, by which Tito received relatively detailed joint weekly information on letters received that week. These letters were also analysed and summarised by the Secretariat, who in February 1968 produced a longer analysis of their contents.

In this 30 -page long analysis ${ }^{1}$ the Secretariat listed the number of letters received and the number of appointments made by Tito's cabinet in each year between 1954 and 1967:

$\begin{array}{ccc}\text { Year } & \text { Letters } & \text { Appointments } \\ 1954 & 25,182 & 8,128 \\ 1955 & 26,639 & 9,165 \\ 1956 & 32,568 & 11,352 \\ 1957 & 30,184 & 13,752 \\ 1958 & 31,898 & 16,666 \\ 1959 & 29,584 & 15,771 \\ 1960 & 28,945 & 15,676 \\ 1961 & 29,507 & 12,775 \\ 1962 & 40,999 & 20,300 \\ 1963 & 30,413 & 15,046 \\ 1964 & 25,924 & 11,427 \\ 1965 & 23,226 & 11,789 \\ 1966 & 31,729 & 10,698 \\ 1967 & 24,961 & 10,374 \\ \text { Total: } & 411,769 & 182,929\end{array}$

1 "Problem i zahtevi gradjana gledani kroz predstavke i pritužbe upućene Predsedniku Republike" [Problems and Requests by Citizens in the view of their submissions and complaints sent to the President of the Republic], 23 February 1968, typed document, 30 pages, AJBT, KPR II-8a, 1968. 
This list indicates that on average, Tito received about 100 letters each working day $-30,000$ per year, and that his office received about 13,000 citizens each year.

The first letters kept by the former Josip Broz Tito Archive in Belgrade (AJBT Fond, now kept in the Archive of Yugoslavia) date back to 1944, and were received immediately after Tito entered Belgrade following its liberation on 20 October. Some of them were really just notes scribbled on a piece of paper, usually signed. Tito read them, and made comments on the top of the paper. Sometimes, the letter would arrive to him together with a short - normally one-page - 'characteristics', an investigative note on the author or the problem, prepared by the security services (OZNA, Department for Protection of the People). The 'characteristics' that accompanied the letters are sometimes as interesting as the letters themselves. They provide a great insight into the behaviour and political attitudes of very many ordinary Yugoslavs during the War, as well as into the role of OZNA in the first years after the Second World War in Yugoslavia. Most 'characteristics' are neither overtly positive, nor overtly negative - but rather mixed. They would normally begin with basic biographical data on the authors of the letter, but would then include information collected by interviewing those who knew the sender - neighbours, police informants, members of their extended family, sometimes party officials in the work organisation. Reading of these short biographies of various people who decided to write to Tito (and to give their full names and addresses) shows a different, more complex, picture than that which the state propaganda projected. Most Yugoslavs, it is obvious from these short notes, could not have been easily described as 'Partisans', 'Ustashe' or 'Chetniks' by what they did (or did not do) during the four war years. Most of them were just 'ordinary citizens', by-standers and observers of the war, who had somebody in their family or among friends who was on one side of the divide, but among their acquaintances and relatives there would also be those who participated in or supported the other side too. It would be even more difficult to describe them as being either very enthusiastic or very hostile about 'new Yugoslavia'. The new regime's propaganda claim, that the Yugoslavs massively supported the new order, or that they massively and actively opposed occupation, was far from what one could read in the characteristics provided by the secret services.

It is, however, rather interesting to notice that Tito seemed to not have minded very much about whether a person who wrote the letter was an active supporter of the Partisans, or just an observer of events. A neutral report on one's war-time behaviour - and most of them could be classified in this category - was not a problem perse.

When analysing the contents of the letters sent to Tito, one can see a change in emphasis: from war-related issues in the first post-war years, towards issues of social (in)justice, (in)equality and (un)fairness in later years. In the first period, there 
were many letters by families of German and other foreign soldiers who did not return to Germany after the war. They were asking for information about the fate of their relatives, German soldiers. Tito never replied to these senders, but in most cases he forwarded the inquiry to OZNA, or the Yugoslav People's Army. In these first post-war years, a large number of letters arrived with requests to locate burial sites, and to allow reburial (in the country of origin) of the fallen soldiers. Yugoslav citizens, too, were often sending letters to Tito, asking him to initiate an investigation into the sites where somebody was buried - and to allow exhumation and reburial.

In 1948-1952, Tito received hundreds, perhaps close to a thousand, of letters by released German prisoners of war - who were finally allowed to return to their countries, having been imprisoned for so long after the end of the war in Yugoslavia. In fact, many German prisoners of war were required to sign a 'thank you' letter to Tito before they boarded trains for Germany. Tito's Archive is full of these letters, some of which also contain paintings and drawings by these prisoners - often in the form of a 'thank you' card.

In the first post-war years, many letters and telegrams arrived with urgent pleas for clemency of those sentenced to death. Most of them were very dramatic in tone, personal and emotional. In some cases, the senders emphasised that a crime for which a person was sentenced had been committed within the context of 'blood revenge'. Although politically he argued in favour of secularisation and outlawed the 'blood revenge', in concrete cases which involved this practice, Tito usually ordered the death sentence to be replaced with life-imprisonment, or a long prison sentence. There are hundreds of cases in which Tito's personal intervention reduced the length of imprisonment, or indeed saved somebody from the death penalty. In some cases, Tito decided not to intervene, and thus he practically 'confirmed' the sentence, as given by the courts. However, the Archive keeps no evidence - not even one case - of Tito's explicit confirmation of the death sentence, or of his insisting that the original court ruling should have been more drastic.

A significant number of letters that Tito received in the first post-war years were concerned with issues of migration - and especially permission to travel abroad, or to receive passport or exit visas which were then required for any exit from Yugoslavia. Tito's response was rather lenient in most cases, although not in those when the applicant was a male person of military age - especially if younger than 30 . In addition, engineers and other experts were unlikely to receive his approval for travelling abroad. Some letters (usually by influential Yugoslavs) sought his approval before they invited a foreign person to Yugoslavia, on a cultural or educational mission. Tito would be asked to facilitate the process of issuing the necessary permits. One of the cases concerned the Patriarch of the Bulgarian Orthodox Church: those who invited him wanted to check with Tito that - given the recent nature of the 
conflict with Stalin (and by extension: Bulgaria too) - it was acceptable to invite him. Tito gave permission, and even commented (in the margins of the letter) that it was "precisely in this moment" in the interest of Yugoslavia that the Patriarch visits.

Many people wrote in these first post-war years (especially in 1944-1950) about poverty, diseases and the poor social conditions they lived in. They asked specifically for medicine (most often against tuberculosis or similar infectious diseases), or for material (financial) support. His interventions on the margins of letters that requested medicine read as doctor's notes, for example: "Penicillin to be given to sender!" His comments on the letters by people living in poverty, however, read like being written by a benevolent and generous owner of a relatively rich country's budget. There are hundreds of letters with his handwritten instruction: "Send him 5,000 Dinars and a letter", or "Send him $81 \frac{1}{2}$ kilos of sugar and 1 kilo of coffee - and a letter!", or similar. In the case of requests for godfathership, the Cabinet and UDBA prepared a report on each applicant. Tito accepted many, but nowhere near close to all requests. However, when he politely declined the invitation, he made sure he "compensated" the sender by sending him a food/clothes package and/or money. With those workers who claimed that they had completed their personal work-plan ahead of time, the procedure was similar: the facts about the sender and the truthfulness of the claim were checked by the secret police and the report would then be returned to Tito. In most cases, Tito would then order the story about the success to be published in newspapers - and he sent a gift to udarnik ('shock worker', a front-line factory worker, a Yugoslav version of the Stakhanovite). The most popular was a pocketwatch, sometimes money, and on very rare occasions he would propose a state decoration or an award for the udarnik. Once this practice became widely known, letters by various potential udarnici became much more frequent, and the Cabinet recommended discontinuing this practice; indeed, it stopped in 1953.

A special case were letters sent to Tito by his pre-war party comrades, or fellow prisoners from the time he served his sentence in Lepoglava and Maribor, as well as by public figures - former Yugoslav politicians, church dignitaries, influential Yugoslav emigrees, and others. Although this paper is not about the correspondence he had with other politicians, statesmen and public personalities, it should be mentioned that public figures wrote to him frequently, and that he usually tried to accommodate their requests. Among his most "regular" correspondents - those who often intervened on behalf of others, or by recommending a problem to his attention - were Ante Mandić, the former member of the Council of Regents (March 1945 November 1945), and a certain Andrea Benussi, a friend from Tito's days of working in Kraljevica's shipyard in the beginning of the 1920s. Mandić's letters were 
frequent - hand-written - and mostly concerned with specific people and their difficulties. Correspondence between Ante Mandić and Tito continued until 1952, when it stopped due to Mandić's protest against the closure of the Catholic (and Orthodox Christian) Faculty of Theology. In his last letter to President Tito, Mandić expressed his deep sadness and disappointment with such a decision and pleaded with President to rethink: as it would turn out, in vain. Benussi never opened any particularly controversial issues, and used his influence to bring various delegations or persons to Tito, that he would accompany personally. Conversations between Tito and the members of these delegations would be rather sporadic and brief - for most of the meeting Tito would talk to Benussi about the old days. Conversations with Benussi are an interesting source, as they contain Tito's personal memories about the time prior to his becoming a political activist in Croatia.

In the immediate post-war period, the largest number of letters sent to Tito were about hardship, social, financial and welfare issues that their senders wanted Tito to know about, and to intervene in. However, some letters were about wider social issues (social justice, fairness, problems with administration and others), whereas some were about particular political issues. Among those, many were about the role of the churches in society, and/or actions taken against particular priests or parishes. The priests of the Mostar Diocese, for example, sent an urgent telegram to Tito, to request his personal intervention against the requisition of the premises of the Bishopry by the Yugoslav Army, for the purpose of turning them into a military hospital in Mostar. Tito investigated the case, and ordered the withdrawal of the armed units from all church premises. This order was given despite the explanation of the action, given by the commander of the health services of the Yugoslav Army, General Gojko Nikoliš, and against his recommendation that the Army should stay in the premises. On another occasion, the Catholic Archbishop Alojzije Stepinac wrote a letter in which he protested against the actions of the new authorities against Church property. Having received no immediate response, Archbishop Stepinac sent two further letters, one more critical than the other, until Tito responded angrily, by saying that the Catholic Church did not fulfil the promise given by the Archbishop himself that it would work in the interest of the people - and thus the state had no obligation to keep its promise not to confiscate Church property. In a third case, to mention but a few, a group of Catholic priests requested a ban of the film "Bakonja fra Brne", which - as they saw it - represented priests in a very unfavourable way, and thus insulted the whole Franciscan order. On the top of the letter, Tito wrote a comment that was then conveyed to the Minister of Interior, Aleksandar Ranković, in which he questioned the opportunism of showing this film at the moment when he was trying to avoid further tensions with the Vatican. The film was not banned, but it was silently removed from the cinema, at least for a while. 
Other political topics very much present in letters Tito received, included in particular: 1) the status and activities of the political opposition, 2) open issues of Yugoslav borders - especially with Italy (over Trieste) and with Bulgaria and Greece (over Macedonia), 3) conditions of imprisonment of various political opponents - including those who were beeing held in an ad hoc labour/prison camp in Goli Otok, and 4) complaints about the behaviour or policies of local branches of the Communist Party of Yugoslavia. In the wake of the first elections, which were held in November 1945, people wrote to Tito with proposals both to allow wider activities of the democratic opposition, and to outlaw them completely. A number of letters were sent to Tito both from Yugoslav citizens, and from Slovenes living in contested areas of Austria and Italy, in which they urged him to take a more decisive position in negotiations on the issue of Trieste, Koruška/Carinthia and on the status of the Slovene minority in neighbouring countries. On several occasions, Tito received various delegations of Slovenes from Trieste, and had open (and often polemical) discussions with them. In private, however, he was less sure than his senders that Trieste should in fact become a part of Yugoslav territory. In conversations he had with veterans of his Partisan movement, Tito admitted that this was not only an unrealistic plan, but also expressed some doubts about the desirability of such inclusion. In the aftermath of the 1948 split with Stalin, Tito received several letters from Macedonians who lived in Bulgaria, in which they asked for additional protection or informed him of coercive actions taken against them by Bulgarian authorities. Among them was a letter by a mother of a Macedonian sentenced to death by Bulgarian courts for allegedly supporting Tito and Yugoslavia.

Complaints about the behaviour of the administration in Yugoslavia were not very frequent, and in most cases arrived in the form of anonymous letters. Among them, some were about the brutal treatment of prisoners in Yugoslav prisons, including - in one or two cases - in Goli Otok, which the secret police and the Cabinet referred to as Camp Marble ("Mramor"). It might be of some importance to notice that such letters rarely ever came to Tito's desk in their original form, but were in almost all cases 're-told' and summarized by the Cabinet. Almost in all cases available in the Archive, the Cabinet would omit the reference to Goli Otok, and would instead use the term "Mramor" to refer to the prison/camp. Of particular interest is a letter sent to Tito in which he was informed in detail about the methods of investigation used by the secret police.

In this first period - that lasted for a long 20 years: between 1944 and 1964 there were no special rules or regulations on how to present the letters by members of public to Tito. It seems that the fate of the letters depended largely on Tito's availability to read them (i.e. on his working schedule and other commitments), as well as on a more or less arbitrary decision by the Cabinet on which letters should reach 
Tito and which should be dealt with by the institution itself. Some were forwarded to other institutions concerned before Tito saw them. Nevertheless, one should notice that Tito indeed saw a very large number of them - and that the decision in most cases was his personally. His involvement was at a level that is truly impressive. He personally read thousands of letters. His decisions - usually written on the top of the letter - were communicated ad verbatim to senders in letters written to them by Tito's Chef de Cabinet. In addition, instructions were given to relevant institutions or heads of these institutions also ad verbatim (exactly as Tito requested in his comments) via the same mechanism.

Tito's direct involvement was in fact characteristic not only of the way he treated the letters he received, but also of his working style in general, in particular in the period until 1964. Tito was a workaholic, who wrote his own political speeches, even when they had - as was the case with his longest and probably the most important speech, the one delivered at the $5^{\text {th }}$ CPY Congress in 1948 - more than 400 hand-written pages. He wrote by his hand the entire first version of that speech, in a relatively short period between March and June 1948, in the months in which it looked very likely that the Soviet Union might intervene in Yugoslavia. The first version of the speech was latter edited by him to such an extent that the second version included re-writing of perhaps half of the speech. Then there were two more edits before he read the proofs. Even the first printed copy of the speech, after being delivered at the Congress, was subjected to his further interventions before it went for publishing. Other major speeches were also largely written by him personally. When he improvised a speech - usually on occasion of visiting various places in Yugoslavia - he spoke from hand-written notes, which looked as if they were written in a hurry, on a train or immediately before being delivered. In these cases, his office requested authorisation. Before broadcasting, the state-owned news agency Tanjug sent the news with extracts from the speech to Tito's press secretary, who did the first editing. The final version would be given to Tito personally for approval. The Archive in Belgrade keeps copies of all versions of such speeches - his notes, the ad verbatim transcript of what Tito actually said at a rally or meeting, the $T a$ njug initial version of the text, the press secretary's edited version, as well as the version that Tito edited and approved for publication. This level of involvement tells us much about the control that Tito wanted to have over his own words and over the image of himself that he was constructing in his public appearances.

\section{A Change of Policy in 1964}

It is in 1964 that some of these practices were abandoned, probably for a variety of reasons. In 1964, namely, Tito's Cabinet went through reorganisation, reflecting the need to introduce some order in the policy of granting access to Tito. The Yugoslav 
President - who was already 72 - won (unopposed) his third term in office in 1964, but his activities (especially those in international politics) seemed to have become more intense than ever before. He was not only the President of Yugoslavia, but also of the Party. In addition, as of 1961, he played a more significant role than ever in international politics - in particular with regard to the newly created association of non-aligned states. In 1963 he met for the first time with an American president, John Kennedy, three weeks before Kennedy's assassination. All this meant that Tito was travelling more than before. In 1961, he was absent from the country for almost two months - from 28 February until 22 April, as he visited Ghana, Togo, Liberia, Guinea, Mali, Morocco, Tunisia and the United Arab Republic (Egypt and Syria). In November 1961 and February 1962, he visited the UAR again. In February 1962 he visited Sudan. In December 1962 he visited the USSR and Hungary. In September and October 1963 he visited Latin America and the USA, on a trip that lasted from 18 September until 1 November. In June 1964 he went to Finland and the USSR, and then he visited Romania and Poland. Little time was left for direct contact with people - either in person or via correspondence.

In response to this new busy schedule, the Cabinet introduced the practice of informing Tito via a regular - usually weekly, but sometimes less frequent -Digest about letters received. Under new regulations, Tito would no longer receive actual letters, but only consolidated information on all letters received (usually statistical - containing the number of letters sent, and who the senders were by their location), and a short one-paragraph summary of those letters that the administration working in his Cabinet considered to be interesting, or important. It would no longer be in Tito's hands to respond or not to any letter that arrived; the pre-selection was now done by the office.

This change of practice shows that by 1964 the direct access to Tito became more restricted and better controlled than in the first two post-war decades. Whereas in the first two decades after the war Tito made an effort to reach out to concrete individuals, this now ceased to be the case. In addition, the new practice shows that the bureaucracy - i.e. professional members of state administration, civil servants received more power that they had before. The time of revolution, the time of direct access to Comrade Tito, and of his direct communication with ordinary people, was coming to a close.

However, there might have been additional reasons for such a change of practice than just Tito's busy schedule, and the ossification of the Yugoslav administrative infrastructure. Throughout the initial revolutionary and immediate post-revolutionary period, Tito used his direct access to letters as a 'control mechanism' upon which he would rely when he wanted or needed to keep 'bureaucracy' (that enemy of socialist revolution) under permanent political and personal surveillance. It is be- 
cause he had direct access to ordinary people (and they to him) that he could check the truthfulness of official information he received from lower instances of governance, secret police sources and other officials. On several occasions in the first 20 years of his rule, Tito complained that he was either not informed, or that he was deliberately misled by various (usually unnamed) 'sources'. On these occasions he often used examples he learnt about not from these official sources (police, party channels, administration and others) but from citizens' letters to him.

The fact that he directly responded to them - and responded by and large benevolently, by granting what was requested - enabled him to establish a 'special link' between himself personally and 'the people'. By creating such a direct bond between himself and many ordinary people, Tito created a large network of those who were grateful and loyal to him, even when - and especially if - dissatisfied with the system. He presented himself to many people as perhaps the only one who cared about them. They complained about bureaucracy, about injustice and unfairness, they told him about how difficult life was, and he responded to that. Word of mouth then quickly spread to friends, neighbours and extended families of those who received his letter and gifts, promoting his legitimacy and popularity more than any declarations and state-sponsored propaganda could. This direct link between him and ordinary people made Tito really powerful. Unlike anybody else in the leadership, he could claim that it was he personally that represented, understood and embodied the will of the people. He understood that very well. In situations of political crisis, he used this position not only to claim that he was the representative of the people, but also to place any opponent or even only a sceptic in a "sandwich" between himself and 'the people'. By doing this he constructed a permanent 'antibureaucratic revolution', led by himself and supported by 'the people' against officials and the system itself. He also made it much more difficult for the system (eg. the state) to construct itself as an independent body.

By 1964, however, other members of the political elite not only understood that it was exactly this 'direct' link that kept them potentially in a no-win situation, permanently squeezed in between Tito and 'the people', but they also started thinking of how to undermine this direct link. The system aimed at making him more dependent on official channels of information - approved reports of Republic/provincial party leaderships, police information and the media, which were increasingly under the control of local political elites in Republics and provinces.

Tito resisted this new system, by stating in public - on more than one occasion - that 'somebody' ('bureaucracy', 'administration') was keeping him deliberately misinformed. On one occasion he even rhetorically asked himself: who is doing that? And replied: "Well, I would have told you who if it were just one person or a small number. But there are so many that I can't name them all." Ordinary people, 
listening to his message, did not really know whether to believe him or not. Some of them did - and thus decided to write to him directly, to inform him 'first-hand'. In these letters, they clearly expressed doubt that the letter would reach him - just as Dragomir Katić did at the beginning of his letter. Through Tito's own public complaining about unnamed bureaucrats who put themselves in between him and the people, he in fact did not lose popularity; on the contrary, he presented himself as an ordinary person, close and similar to them. In authoritarian regimes, people were often led to believe that the person on the very top in fact did not know about their problem. "If he only knew, everything would be different." Thus, there was a need for them to write - to tell him the truth.

All this power-struggle between Tito and 'bureaucracy' (represented by the two pretenders: Ranković and Kardelj, as well as by various Chiefs of Staff, members of the Party leadership and others) happened at the same time when in Moscow a similar situation forced the leader, Nikita Sergeyevich Khrushchev, to resign under the orchestrated pressure of the 'young bureaucrats', such as Leonid Ilych Brezhnev and Nikolai Podgorni. The ousting of Khrushchev - who was seen both by Tito and by the Yugoslav population in general as a reformer, and to a degree 'a man of the people' - sent a clear signal to Tito too. If Khrushchev, the leader of the Soviet superpower, could have been forced to step-down by 'anonymous bureaucrats', then anyone in the socialist world could. Tito tried to avoid a similar turn of events by turning against 'bureaucrats' (such as Aleksandar Ranković, who was ousted from powerful offices in 1966) and by keeping his direct links with ordinary people intact.

\section{Critical Letters to Tito after 1964}

Dragomir Katić's letter arrived in the period when the power of 'bureaucracy' was getting stronger, despite the fact that Ranković was ousted a year earlier. In fact, it was between 1964 and 1972 that Tito had to re-affirm his own position pretty much continuously. By restricting his access to people's letters, the 'bureaucracy' (and in fact, a political coalition based on the concept of further decentralisation) succeeded to a degree in making Tito less popular than he was before. This in turn made people more critical of him, which is probably what those who imposed the 'reorganization' in fact wanted to happen. This can clearly be demonstrated by content analysis of the letters that were sent to Tito's office after 1966. Both by their main subject and by the tone, they were very different from the ones in the 19461964 period.

Letters that citizens sent to Tito after 1964 were much more political in their character than those before this period. While in the first two decades of socialism, people were asking for his direct help with various social and legal issues, by the 
mid-1960s they moved towards discussing political issues that they disagreed with or did not understand.

In 1964 (undated) an anonymous letter arrived, signed by "a group of workers and administrative workers of the wider Belgrade area". ${ }^{2}$ The authors, who claimed they were writing "on behalf of at least 2,000 workers from Belgrade" argued that the costs of living were getting "more difficult by the day". Many of us are communists and not enemies, but - "believe us, Comrade Tito, the working people are very dissatisfied with the prices rising, in some cases threefold or fourfold since the beginning of the year". People are starving, they wrote. Our salaries are not enough to pay for rent, electricity, water, milk, radio, public transport and various loans - not to mention other issues, such as clothing, school books for children. The devaluation of the Dinar is a shame, so that today it is worse than it was in the time of [Milan] Nedić [the Quisling ruler of Serbia during the Second World War], and worse than was the shameful Croatian Kuna [during the Independent State of Croatia, also in the Second World War]. It is "boiling among the people", and this could reach the point of no return - and "nobody sees how difficult it is". Managers are "completely bureaucratised", nobody can do anything about/against them, because "they have taken all power into their hands, and they don't care at all about self-management". Those who oppose them, or criticise them, are becoming their victims. The trade unions do not help at all.

We managed to liberate ourselves [in the Second World War] and we were successful in re-building our country. But we also want to keep our jobs and to be able to live on what we earn, if not to save. We shouldn't starve to death.

Such discontentment with the system was now to be heard everywhere, they warned Tito. "Those of us who are not engineers, or Directors, or who do not belong to their small circle - are ruined." The letter ends with a clear warning:

Do not be surprised if the worst happens. We write to encourage you to take some steps so that people begin living better.

Tito saw this letter - he acknowledged reading it by initialling it on the top, with his characteristic signing "VT" ("vidio Tito": "Seen by Tito"). Unlike this, there is no evidence that an anonymous letter sent to him by an individual (who said: "I don't dare to sign it") on 21 August 1964 ever reached him. In this letter ${ }^{3}$ the author wanted to inform him that "there are so many irregular and illegal practices at work that an honest and principled person simply cannot but feel cold in his soul". The writer then mentioned two cases of suicide - one by a certain Mr. Lazić

2 AJBT, KPR II-8a, 1964, 5 pages, typed.

${ }^{3}$ AJBT, KPR II-8a, 1964, 4 pages, typed. 
in Belgrade and another by a Mr. Tanasković in Sarajevo - implying that these were only consequences of living in an unfair society.

The overall situation is so bad, that one can see that You [i.e. Tito personally] are not capable of implementing any of Your ideas on how to defeat this rotten situation, and neither can You do anything against those who produced it. Those who find joy in this corrupt situation have lost any sense of shame in front of honest and hard-working people and in front of the working masses... There is an enormous gap in our society between the aristocratic standard of the millionaires and the living standard of all other people who live in poverty because they are not and neither do they want to be in this privileged category.

The author concluded that "there is chaos in the market and in the economy in general".

Those who present to you any different picture, they lie to you. There is a very significant discontent among the people - who cannot accept differences between us and them, and who will not agree with their privileges. In particular, people are angry because our complaints and criticisms are ignored.

Who is responsible for that, rhetorically asked the sender. "You, up there!", he answered his own question.

The reputation of socialism and of the LCY is more important than any of us as individuals... Thus, you should take it very seriously, and be deeply worried about these problems, which last for far too long. This should be done without any sense of self-indulgence and without ignoring the problem.

Another semi-anonymous letter arrived to the Cabinet (but not necessarily to Tito) on 9 October 1964, signed by "Your loyal Partisans of 1941 and Communists". 4

Comrades, in this situation nothing is impossible, especially now when the living standard is diminishing every day, and it should not have been so. You should know that - there is nothing the one who is hungry cannot do, he is capable of doing anything. We beg you to think twice before you do something, because again everything is possible, and when the impossible happens it will be too late.

In another anonymous letter, sent probably sometime in 1964 or in the first half of 1965 by "Engineer N.N.", who said he personally knew Tito from before the War and from the War, the current political and economic situation was described as being almost tragic.

It is very sad to see that $3 / 5$ of the land has no access roads, that people look like they live in concentration camps, that workers and miners earn 20-30 thousand

${ }^{4}$ AJBT, KPR II-8a, 1 page, typed. 
Dinars, that a poor patient, if he does not know anybody, cannot be admitted to hospital - unless he pays to the Doctors 10-20 thousand Dinars in bribes, that the mad Mafia made of irresponsible managers behave in a way very similar to private employers in capitalism, that the local leaders behave no better then pre-war mayors, that the poor and exhausted workers are treated as thieves and that they are hunted by police, while those who speculate with money and are lying in public are seen as model-citizens, who are immune to any prosecution.

The author urges Tito to "introduce some order", because people are hard working, but leaders are the source of the problem. Why can't they enjoy the same level of living standard as those who live in the West? If this continues, the writer said, even India would become a better and more prosperous place than Yugoslavia. He invited Tito to use "military discipline" in order to remove various "managers and charlatans" who are the main problem.

On 17 July 1965, another anonymous letter arrived to the Cabinet (again: not read by Tito) from Belgrade. ${ }^{5}$

Do You [personally] really believe that workers are in charge of factories? When You say that the workers manage the factory, people laugh at You, because everyone knows the real power is with General Managers and various Party Committees. They sit on all the Workers' Councils, and in the executive board of the firm - it's only that their seats are behind the curtain, and You don't see them. Others can't complain or ask questions, because they will lose their jobs if they do.

The anonymous writer then concludes:

My intention was to tell You [personally] about this, because this is all being done without Your [personal] knowledge, since You [personally] would not have approved it.

In another letter that Tito read and initialled, 6 "a Communist since 1926" wrote to him:

Dear Tito! You started well. The Letter the Executive Committee of the LCY sent, as well as Your speech in Split, was like a much-needed medicine to a seriously ill patient - but then: either those around You misinformed you then, or You were forced to give in to various pressures. I must tell You - and this is not only what I think, but also what our people think - that You have lost this battle, and that things have continued the usual bad way, if not even got worse than ever before. In short, Your ideas have not borne any fruits. If You wish to do that when You are still alive - and You are the only one with some respect among the people - then

${ }^{5}$ AJBT, KPR II-8a, 2 pages, typed.

${ }^{6}$ AJBT, KPR II- 8 a, 5 pages, typed. Tito initialed it on page 1. 
You should do what You can for this system to be taken out of chaos and anarchy. It is hard to find words to describe the anomalies in our social system... Corruption and bureaucracy reign, and this just simply cannot be tolerated... They are all lying to You: from municipal committees onwards, because all of them want to present the real situation in their own territory much better than it actually is, so that they can get an even better position tomorrow. There is no morality left, and no ideals are alive any longer: everyone is now running after positions and large sums of money. The workers' self-management is proclaimed - but the situation is worse than in any capitalist country. There is not even a trace of it in reality, as the only people who really make decisions are managers and a couple of their closest friends. We are in fact not doing ourselves any favours when popularizing that system. Nobody asks workers about anything...

The author then continues to complain about increased costs of living, and about inequality before the law. Those who criticise reality are quickly pushed aside, and nepotism and mutual favouritism reign throughout the elite.

Get out - among the people and see for yourself what is really happening. Don't forget what You told us in Your speech in Split. Talk to the nation - people are behind You and You won't be lonely. If needs be, we will fight again - just like in the last war - with You, just to sort out things for the benefit of the people and socialism.

This letter too (just like the previous one) warns about the unpredictability of people's discontent.

We can only be happy that we haven't had major problems with people so far, but one should not really believe that this might not happen soon. In fact, I expect it to happen any moment now... and then we will lose everything we had fought for.

In a letter that arrived from Celje (Slovenia) in January 1966, an anonymous author threatened the communists.?

Injustice and high prices everywhere! My children ask me to buy apples to them - and I can't, because they are too expensive. At the same time, those up there [members of the elite] have everything: high salaries, they travel abroad, and so on. What else should our people tolerate? First under Hitler, and now under Tito. Who else is going to ride our backs? Small salaries, small pensions. We send our best food to Capitalists [the West], and only the garbage remains to us - and we also import it. Hard currency produced by the people in Yugoslavia and our workers abroad are being spent on parties and cocktails - for our Liberators - those who live high without ever really working at all, just like You do [personally].

${ }^{7}$ AJBT, KPR II-8a, 1 page, typed. 
And even today we are working for You - for all of you who robbed us of our flats and are now occupying them, while we are suffering in various communities. When worst comes to the worst, you communists should catch the heaven. I tell you - the money you stole from us will not be good enough for us. You came to power by killing your own people, and that's how you will end too. The people are ready!

Similar criticism - and sometimes open threats - were coming from other parts of the country, not only from Serbia and Slovenia. The summary information on the letters the Cabinet prepared for Tito on 20 September 1965 noticed that most of them were critical, especially on the issue of economic reforms started in 1965. In this year, Yugoslavia opened more widely its doors to private initiative - especially in tourism (including to foreign tourists) - and initiated structural reforms that aimed at increasing industrial output. Many saw these measures to be a return to capitalism. A more restrictive employment policy made it more difficult than ever for young people in particular to find a job. At the same time, the older generation legitimised not by their educational or working qualifications, but rather by political and ideological loyalty (and participation in the Partisans) - was still in control. The new, post-war generation, better educated, with higher expectations and less ready to compare the new realities with either wartime or pre-war austerity - was now for the first time entering the job market. However, due to new practices as well as the economic situation, there were no jobs, and access to those that were available was strictly controlled by a widespread network of personal links and support ("veze i poznanstva"). It was thus the logical conclusion they reached - that socialism was failing them, both because of the 'return to capitalism' and the 'strong bureaucratism'. What hurt most, however, was not that there were no jobs and that salaries were relatively low, but that injustice and unfairness reigned supreme in a socialist country that was meant to be built on principles of justice and equality. Subsequently, many of them - especially among the younger Yugoslavs - decided to leave to other countries (especially Germany and Austria) in search of jobs. This was neither the result of their ideological belief in liberal democracy, nor necessarily evidence of their personal ambitions. They left because they had no jobs at home. They left disappointed - and many felt abandoned by their own country. Their migration to the West (which, in the ideology professed by Yugoslav communists, was in its 'permanent crisis') was not only a problem for Yugoslavia's reputation abroad, but also a potential problem for its defence and foreign policy. As would become obvious only in the last years of Yugoslavia (the end of the 1980s and the beginning of the 1990s), some of those who had left in the mid-1960s returned as bitter enemies of both socialism and Yugoslavia. They would come to play a significant role in the disintegration of the state as well as in the conflict that followed. 
At the same time, those who stayed in Yugoslavia were also dissatisfied. The Notes on the letters received on 20 September $1965^{8}$ include a quote from another anonymous letter sent from Zagreb:

It would be better for You to obtain from somewhere an atomic bomb, so that you can throw it on Your people. But You [personally] and Your comrades should hide well in a deep basement. After all, You have the means to live there long, unlike the rest of us - unlike the poor people of this country.

Similar is a threat from Mostar, quoted in the Notes. The "workers of Mostar" wrote to him that unless things got better soon, they would "organise sabotage in their workplace - worse than they did to the occupiers during the war".

Tito, who read some of these letters, must have been seriously worried.

\section{Meeting Comrade Katić}

The letter Dragomir Katić wrote to him in February 1967 should be read in this context. The sense of urgency and alarm that this letter triggered with Tito is evident from Tito's handwritten comment on the top of the first page of Dragomir's letter. In black ink, Tito wrote an instruction to his Chief of Cabinet: "Invite this Comrade to me - tomorrow, 25. II, at noon or afternoon, for discussion. Send a car for him. T.",

Tito made his decision not only on the basis of the letter Dragomir sent to him two weeks earlier, but also based on a short one-page information on its sender. ${ }^{10}$ The information said that Dragomir K. was born on 6 August 1936, that he was married, and became a member of the LCY on 26 October 1961. Before becoming a Party member, he was a functionary in the Youth Organisation and in a trades union. He was also a journalist for a while (Tito underlined this last fact). Those who investigated his past said that in his application for LCY membership he wrote that his brother and sister were both killed as victims of Fascist terror, and that his father was a prisoner of war in Germany. As a consequence of torture in the camp he became permanently disabled. "We had no opportunity to verify these claims", it was said in the information.

His immediate family is of good character. His brother and a sister-in-law are members of the LCY. The brother participated in various voluntary public work actions, where he distinguished himself. [Dragomir] was injured in an accident in 1951, and since then has been declared 50\% disabled. He was employed in the

8 Beleška, 20. IX 1965., AJBT, KPR II-8a, 1965, 2 pages, typed.

9 AJBT, KPR II-8a, 1967, the letter sent on 10 February 1967, Tito's comments written on 24 February 1967, 5 pages, typed.

${ }^{10}$ AJBT, KPR II-8a, 1967, 1 page, typed, Tito's signature (J B Tito) and VT on the top of the page. 
'Pletar' factory, and as of 20 July 1960 he worked in 'Papirpromet' in Kraljevo. There he entered into a conflict with the manager, who demoted him from the management of the firm into a tobacco shop, where he became a tobacconist in the factory's kiosk. The manager ordered this move in his letter to the secretary of the factory. However, the secretary then complained about this and other cases to the Central Committee of the LC Serbia, in a letter of 5 May 1966. It seems that in this case we are talking of animosities towards him because of his ambitions - because in this particular firm very few people have adequate qualifications. Dragomir is known as a positive person. He completed his education under very difficult circumstances, and had a reputation of a good worker and good member of the LCY. According to the statement by the political secretary of the Municipal Committee of the LCY in Kraljevo, he came to talk to all socio-political institutions in municipality, and apply for jobs - even when these jobs would be for people with lower qualifications: but could not get any job. On several occasions he spoke to the Secretary of the Municipal Committee, who tried to intervene in order to help him in finding a job, but he has always been unsuccessful.

The next day, 25 February 1965, Tito met Dragomir Katić in his official residence in Belgrade. The transcript of this conversation has been preserved in Tito's Archive. ${ }^{11}$ There are very few transcripts of similar meetings with ordinary members of the public who sent letters. Tito would indeed sometimes meet politicians, or comrades from old days who were personally known to him when they wrote to him. But, to meet an unknown person - and, one should not forget, a person who wrote a rather critical letter to him - was a precedent.

The conversation between Tito and Dragomir Katić offers a unique insight not only into Tito's personality and style of governance, but also into the wider political circumstances in which the meeting took place.

Tito was on the defensive for most of the conversation, while Dragomir Katic remained firm in his criticism of 'bureaucracy'. Nevertheless, he saw Tito as his ally, rather than as a part of 'bureaucracy'. On Tito's direct question - whether it was a system or 'individuals' that should be blamed, he offered a clever answer, blaming 'individuals' but not failing to mention that in fact the system was made up of individuals. The Party, to him - as to Tito - was the key. Both Katić and Tito indicated that there are limits to what Tito could in fact do: Dragomir Katić said that he might be in trouble for meeting him, and Tito openly said he could do much more within the Army than in other institutions if he wanted to solve any problem. He even asked Katić to send another letter to see if it would reach him, or be stopped by the 'bureaucrats'. He promised to help, but openly admitted that he was not in a position to deliver on all his promises.

11 AJBT, KPR II-8a, 8 pages, typed, 25 February 1967. 
What followed after this meeting, however, was truly astonishing, as it in fact clearly indicates all the weaknesses of Tito's position in the years between 1967 and 1969 - thus, before he decided to take a number of rather decisive actions against 'bureaucracy' again (in 1971-3). In short - despite Tito's personal intervention, it took another two years before Dragomir Katić finally got a job as a junior (probationary) administrator in the Municipal Assembly of Kraljevo. He started working only on 3 March 1969 - 737 days after his conversation with Tito.

Throughout the two years of waiting for a job, Katić kept sending new letters to Tito, who did not reply to any of these - although he was informed of the development of the case, and on several occasions his Cabinet urged other institutions to take action.

On 1 April 1967, Tito was informed by Dobrivoje Radosavljević, then President of the League of Communists of Serbia, that - following his meeting with Katić - a member of Radosavljević's Cabinet went to investigate the case. ${ }^{12}$ The investigation board concluded that the problem of finding employment was rather general, and Dragomir Katić was only one of these cases, not a special case. Dobrivoje Radosavljević concludes in his letter to Tito that "despite all these general problems, the comrades in Kraljevo will try to find a job for Dragomir Katić". This fairly non-commital letter shows that the local leaders in Kraljevo - as well as Serbian party boss Radosavljević - de facto rejected Tito's personal intervention. They did not even promise anything - just that they would try to resolve the problem.

As nothing in reality happened, Dragomir Katić decided to write another letter to Tito. In the letter he wrote in June 1967, he informed Tito that there were no improvements in his status, except that the court decided he was not guilty of any misconduct back in 1964, but this did not mean he would be allowed back to work. Deeply disappointed and obviously agitated, Dragomir Katić said that he had lost any confidence in the LCY, and was thinking of radical actions:

If You think I am distorting the truth, then please allow me to go to Vietnam or Egypt if the situation there doesn't get better. I want to die, but not in vain. One should fight in life. You know this very well, since you have never stopped fighting. So, let me be a volunteer in Egypt or Vietnam - I am sure I would not be less capable as a fighter than a large number of our brothers and sisters, who died under Your flag during the war.

The Cabinet informed Tito that the letter arrived, and quoted this paragraph in the summary. It also said that the original letter was forwarded to the Executive Committee of the Central Committee of the Serbian LC. The fact that the letter was

12 AJBT, KPR II-8a, one-page letter from Dobrivoje Radosavljević to the Cabinet of the President of the Republic, reg. no. 215/1, of 1 April 1967, received under reg. no. 182/2. 
forwarded to the leadership of the republic before Tito saw it, was in part a result of decentralisation. As of 1974, most letters received by the Cabinet would automatically be forwarded to the leaders of the Republics/provinces: even those in which the senders complained about them. ${ }^{13}$

Having received no response, Dragomir Katić kept applying for jobs - but in vain. According to a third letter sent to Tito in February $1968,{ }^{14}$ in addition to 120 job adverts he applied to before meeting Tito, Katić applied to another 30 since the meeting took place - but was in all cases unsuccessful. In this third letter, which the Cabinet again forwarded to Serbian leaders, Dragomir Katic asked for another meeting with Tito. The Cabinet decided he should meet with the Serbian party's Control Commission, and talk to them, rather than to Tito personally. The decision was taken by the Cabinet, and Tito was only informed about it.

In November 1968, the fourth of Dragomir Katić's letters arrived to the Cabinet - for Tito personally. ${ }^{15}$ This letter was not forwarded anywhere, but it is not clear whether Tito saw it or not. There is some underlining of various paragraphs on the original letter (which might have been done by Tito, or by a member of his staff), but there is no characteristic sign of Tito's reading it (VT). In this letter, Katić says that 20 months have now passed since his meeting with Tito, "but nothing happened, no job".

Believe me, in 40 out of these 60 adverts, those who won were less qualified than me.

"I understand", wrote Dragomir Katić to Tito, "that you must be busy, and that you cannot pay much attention to small things such as this one." Nevertheless, he asked Tito to meet with him again, as it was now four years that he was unemployed. He wrote he would come to Belgrade, "and stay there until You find time to see me" "because I don't have any place to return to, and neither have I any reason to return."

You are my only hope, and it is only You that can help me now. I know You are more powerful than that local bureaucratic bunch down there.

The fifth letter was sent to Tito on 18 February 1969, from Kraljevo. ${ }^{16}$ Dragomir Katić, who did not achieve anything through his previous letters, now threatened to use "Tito's and Moša Pijade's method" - probably a strike - to achieve his objectives. He even hinted at leaving the Party altogether - "which would be with

13 On this, see Note on the letters of 18 February 1974, AJBT, KPR II-8a, 1974, p. 6.

14 AJBT, KPR II-8a, the Note by the Cabinet, 29 February 1968, 2 pages, typed, reg. no OU-Stp [strictly confidential], 186/67.

15 AJBT, KPR II-8a, letter of 1 November 1968, 1 page, typed.

16 AJBT, KPR II-8a, letter of 18 February 1969, 1 page, typed. 
heavy heart, as I love and appreciate the League of Communists above anything else". He still did not lose faith in Tito personally, and even said in this letter that "You [Tito] do not deserve it" [what he would do].

Although there is no evidence that Tito read this letter, on 21 February 1969 the Assistant Chief of the Cabinet, Marko Vrhunec, sent a letter to the Secretary of the Serbian League of Communist's CC Secretariat, Latinka Perović. ${ }^{17}$ Vrhunec asked Latinka Perović to "get involved in the case, and to find a way to help him". In addition, Vrhunec asked her to report back to him, so that he could inform Comrade Tito of any action taken.

It is in fact that last intervention that finally - after two years - solved the case. In a letter of 10 March 1969, an official of the CC LCS (not Latinka Perović herself) wrote back to the General Secretariat of the President of the Republic, ${ }^{18}$ informing them that Dragomir Katić obtained a permanent job in the Municipal Assembly of Kraljevo.

According to information we received, Dragomir Katić is personally happy with the job and with the salary, and thus we take it that this case is now completely closed.

And indeed, the General Secretariat of the President classified the case as being ad acta on 19 March 1969.

On 21 August 1969 - almost half a year since he started working - Dragomir Katić wrote his last letter to "Dear Comrade Tito". This was a 'thank-you' letter of three pages. Katić explained that he did not want to write earlier, because he wanted to be sure that his job was now safe. He said he got a job that is below his qualifications, and that the job itself is probationary, but also that he now has all confidence that this would change internally. He thanked Tito wholeheartedly for finding time to receive him in February 1967. His tone now changed and Katić wrote:

I am still very much impressed with the fact I went to see my President and the President of the LCY, because this showed me that he indeed cares when somebody harms a poor man such as Dragomir Katić. I am glad for that, because the country that has such a President will never be broken. I am happy and at peace because justice has won once again. You recovered all my once lost trust in people and in the LCY, although I never lost trust in the Party, not even for a short

17 AJBT, KPR II-8a, letter of 21 February 1969, from Marko Vrhunec to Latinka Perović, Str. Pov. [Strictly Confidential] no. 182/67, 2 pages, typed.

18 AJBT, KPR II-8a, letter of 10 March 1969, signature illegible, from "Director of the department for complaints, CC LCS", reg no. Str. Pov. 3/1. Received by the General Secretariat and registered under no. St. Pov. 182/8. 
while - because the path we have taken is good and it is in fact the only true path one should take.

These lines in Dragomir Katić's last letter indicate that - as soon as he solved his own problem - he became again a faithful and loyal member of the LCY. No trace of criticism of the whole system remained in evidence in this letter, and no announcement of any further political actions. Dragomir Katić became once again a good, loyal and patriotic Communist, a believer in Tito, the Party and the system. He remained critical of 'bureaucracy', but so was Tito himself. He now, once again, and in fact to an extent much larger than ever before, relied on Tito personally. It is only Tito, he wrote, who could in fact solve all the problems of 'ordinary people' like him. The fact that he waited for so long to see injustice annulled was now entirely forgotten. And so were the cases of so many other people around him, that never had a chance to meet Tito and to rely on his personal intervention. Comrade Katić was now not interested in their cases: he solved his, and that is all he ultimately wanted. Other people's problems were their business - not his. He certainly would not initiate any collective action now that his problem was ad acta. On the contrary, as a re-affirmed Titoist, had such an action been organised by them, we should assume that he would have been more likely to oppose it rather than support or participate in it.

\section{Conclusion}

What does this particular - and to a large extent unique - case tell us about the nature of legitimacy of Tito's rule in the key years of Yugoslav socialism, in the period when the system moved from its third to its fourth constitutive period? Further, what does the analysis of letters sent to Tito during the long period of his rule tell us about his style of governance, and about the Yugoslav social and political system in general?

We will first focus on the former issue: the lessons of the case of Dragomir Katić, only to move to the latter - the importance of letters for explaining the nature of Titoism.

The case of Dragomir Katić shows that Tito found himself in the mid-1960s in a unique situation in which he was not really sure that he understood the nature of people's complaints about the system and individuals who operated within the system. He felt insecure about information that was - as of 1964 - filtered on the way to him. He had not forgotten about what happened to Khrushchev, and he wanted to take a decisive action against 'bureaucracy' in order to prevent action (real or perceived by him) against his rule. This was why he ousted Aleksandar Ranković in 1966 and the leaders of Croatia in 1971 and Serbia in 1972. This is also why many people supported him in these decisions. He felt that by introducing mechanisms 
of control and selection of letters (as of 1964), the 'bureaucracy' was in fact trying to prevent him from using one of the main instruments by which he had always secured his own political position: the direct link between him and the people.

Whereas he hoped that the ousting of Ranković in 1966 would be a hard blow to the 'bureaucratic' apparatus's ambitions, the anonymous letters he received in the following months were just as critical, if not even more critical, as those from before July 1966. Dragomir Katić's letter was among the first signed with a full name and address - and Tito used the opportunity to invite him for a conversation.

However, the apparatus clearly demonstrated its strength in the two years following Tito's meeting with Dragomir Katić. Tito simply could not find him a job and this was despite the fact that it was very clear to everyone involved that he was personally behind the attempt to resolve Katić's case. This fact shows Tito - whom the system portrayed as being the most powerful, and an omnipotent figure in Yugoslav politics - in an astonishingly different light.

Katić's letters - just as most anonymous letters he received prior to that one showed that people too somehow instinctively felt that he was not omnipotent. They did not blame him for everything (despite Katić's angry accusation that he personally was to be blamed for everything). They saw him as a lonely supporter of their causes, and a person whom they could trust, because he was the only one who really cared about their interests. Interestingly, many of those who wrote to Tito saw him as being an almost isolated ruler, the one who is besieged by the 'evil' bureaucracy. However, both sides knew that it is only if they work together, in coordination, that they can "squeeze" 'bureaucracy' in a sandwich. As a certain T. Žanetić, who wrote a letter to Tito on 27 June $1968,{ }^{19}$ said:

Let's do it together: you from the top, and we from the bottom, so that we can meet in the middle of the tunnel and hug each other.

Direct access between Tito and the individuals was a key to his policy of a permanent 'anti-bureaucratic revolution'. On the other hand, it was precisely his access to letters that increasingly worried 'bureaucracy', which firstly introduced information and summaries instead of direct access in 1964, then decided in 1974 that most letters should simply be forwarded to Republics and provinces, only to discontinue the administrative post in Tito's General Secretariat in charge of letters (on 22 May 1975). ${ }^{20}$ Later that year, on 14 October 1975 , all letters were automatically sent to the collective Presidency of SFRY, and only some would then from this institution be forwarded to Tito. This was the effective end of Tito's contact with reality.

\footnotetext{
19 AJBT, KPR II-8a, letter by T. Žanetić.

20 See Note of 22 May 1975, AJBT, KPR II-8a.
} 
In the last four years of his life, Tito remained a symbol of Yugoslav unity, but he also lost almost all institutional and real political power. The collective leadership replaced him as the real head of state, and the new Constitution (of 1974) treated him as a 'tolerated exception'. His naming in the text of the Constitution was evidence not of his omnipotent power (as often interpreted by some academics) but of an extra-constitutional position, that would disappear once he died. In the last years of his life, no letters with any serious contents broke the sound-proofed wall around him. When they reached the Secretariat, they were forwarded to 'Comrade Stane Dolanc' (the new Executive Secretary of the LCY) or some other official, who - almost in all cases - wrote on the top: "There is no need for Comrade Tito to be disturbed with this." The 'bureaucracy' had won. When Tito died in May 1980, it was perhaps primarily for that reason that many people felt abandoned and insecure. This is why many wept at his funeral on 7 May 1980.

Mailing Address: Dejan Jović, Faculty of Political Sciences, Lepušićeva 6, 10000 Zagreb.E-mail: dejan.jovic@fpzg.hr 